\title{
REKONSTRUKSI OBYEK TIGA DIMENSI DARI GAMBAR DUA DIMENSI MENGGUNAKAN METODE GENERALIZED VOXEL COLORING-LAYERED DEPTH IMAGE
}

\author{
Rudy Adipranata ${ }^{1}$, Kartika Gunadi ${ }^{2}$, Victor Julian Lipesik \\ Jurusan Teknik Informatika, Fakultas Teknologi Industri, Universitas Kristen Petra \\ Jl. Siwalankerto 121 - 131, Surabaya 60236 \\ E-mail :rudya@petra.ac.id1, kgunadi@petra.ac.id²
}

\begin{abstract}
ABSTRAK: Pada penelitian ini dikembangkan sebuah perangkat lunak untuk merekonstruksi obyek tiga dimensi dari kumpulan gambar dua dimensi dengan menggunakan metode generalized voxel coloringlayered depth image (GVC-LDI). Metode GVC-LDI ini melakukan rekonstruksi dengan bantuan link list LDI guna mencari voxel-voxel yang merupakan bagian dari obyek tiga dimensi berdasarkan warna. Guna penentuan voxel tersebut dilakukan perhitungan dari pixel-pixel yang merupakan proyeksi dari sebuah voxel. Perhitungan dilakukan dengan menggunakan standar deviasi warna untuk menentukan apakah pixel-pixel yang bersesuaian mewakili lokasi obyek yang sama. Apabila standar deviasi warna lebih kecil dari threshold maka dapat dikatakan bahwa voxel tersebut termasuk bagian obyek. Proses ini dilakukan secara berulang untuk semua voxel hingga didapatkan voxel-voxel yang merupakan bagian dari obyek. Voxel tersebut kemudian digambar pada layar monitor sehingga diperoleh hasil berupa obyek tiga dimensi yang menyerupai obyek asli yang terdapat pada gambar dua dimensi. Pada penelitian ini juga dilakukan perbandingan antara metode GVC-LDI dengan metode Generalized Voxel Coloring-Image Buffer (GVC-IB) yang juga merupakan varian dari metode GVC. Pengembangan dari perangkat lunak ini adalah pembuatan aplikasi 3D modeling secara otomatis dan pembuatan aplikasi animasi 3D secara real time.
\end{abstract}

Kata kunci: rekonstruksi tiga dimensi, generalized voxel coloring, layered depth image.

\begin{abstract}
The objective of this research is to develop software which capable to reconstruct $3 D$ object from $2 D$ images as references using Generalized Voxel Coloring - Layered Depth Image method (GVC-LDI). This method reconstruct 3D object using LDI link list as help to find voxels which correspond to the objects based on color. To find the voxels, we calculate the color standard deviation of the pixels which is projected from the object. If the standard deviation is smaller than the threshold, the voxel evaluated as a part of the object. The process repeated for each voxel until it gets all of the voxels which shape the object. The voxels can be drawn to screen to get the photorealistic $3 D$ object that represent the $2 D$ images. In this research, we also compare the result of GVC-LDI and Generalized Voxel Coloring-Image Buffer (GVC-IB) which is one of the GVC variant also. Future development of the software is automatic 3D modeling application and real time $3 D$ animation application.
\end{abstract}

Keywords: 3 D reconstruction, generalized voxel coloring, layered depth image.

\section{PENDAHULUAN}

Hingga saat ini, rekonstruksi obyek tiga dimensi yang berasal dari obyek real merupakan bidang penelitian komputer grafik yang masih aktif. Hal ini dikarenakan banyak aplikasi yang membutuhkan rekonstruksi tersebut, seperti virtual reality, $3 D$ modelling secara otomatis, augmented reality, dan lain-lain. Banyak metode yang telah dikembangkan untuk melakukan hal ini dimana secara garis besar metode tersebut dapat dikelompokkan menjadi dua bagian yaitu image based rendering dan image based modeling.

Perbedaan antara image based rendering dengan image based modeling [1] adalah dari proses yang dilakukan dimana pada image based modeling banyak dilakukan perhitungan matematis untuk melakukan rekonstruksi dari obyek dua dimensi sehingga menjadi geometri primitif yang pada akhirnya menyusun sebuah obyek tiga dimensi. Sedangkan pada image based rendering, proses dilakukan dengan melakukan analisa dari gambar 2D untuk menentukan bagian mana yang merupakan obyek tiga dimensi sehingga hasil keluaran adalah suatu bentuk gambar sintetis berupa obyek tiga dimensi yang direkonstruksi. Salah satu analisa yang sering digunakan pada gambar 2D untuk membentuk obyek 3D adalah analisa warna.

Pada image based rendering, mempunyai keuntungan mudahnya melakukan rekonstruksi suatu obyek yang bersifat photorealistic. Obyek photorealistic adalah sebuah obyek yang berasal dari obyek sebenarnya pada dunia nyata, jadi bukan obyek yang 
merupakan hasil manipulasi atau kreasi dengan menggunakan perangkat lunak pengolah gambar. Sedangkan image based modeling untuk dapat melakukan rekonstruksi obyek photorealistic masih harus menggunakan metode lain seperti texture mapping.

Pada penelitian ini digunakan metode pada kelompok image based rendering, yaitu Generalized Voxel Coloring-Layered Depth Image yang dikemukakan oleh Greg Slabaugh [2]. Metode ini merupakan pengembangan dari metode Voxel Coloring yang dikemukakan oleh Seitz dan Dyer [3]. Metode Generalized Voxel Coloring (GVC) sendiri mempunyai dua varian yaitu Image Buffer dan Layered Depth Image [2]. Pada penelitian ini dilakukan implementasi varian Layered Depth Image dimana hal ini merupakan kelanjutan dari penelitian yang telah dilakukan sebelumnya yaitu implementasi varian Image Buffer [45]. Metode GVC Layered Depth Image mempunyai keuntungan mempunyai proses perbandingan yang lebih sedikit dibanding Image Buffer. Pada saat pengujian juga dilakukan perbandingan dengan menggunakan metode Image Buffer yang telah diimplementasikan pada penelitian yang terdahulu [4].

\section{KALIBRASI KAMERA}

Kalibrasi kamera adalah salah satu langkah yang harus dilakukan dalam proses rekonstruksi 3D, dimana proses ini diperlukan untuk mendapatkan informasi parameter kamera yang digunakan untuk melakukan transformasi dari 3D (world coordinate) menuju ke 2D (camera coordinate). Ada beberapa metode yang sudah dikembangkan untuk melakukan proses kalibrasi kamera. Metode-metode ini dapat digolongkan ke dalam dua kategori, yaitu:

- Photogrammetric Calibration. Proses kalibrasi kamera dilakukan dengan mengamati obyek kalibrasi dimana geometri dalam ruang 3D telah diketahui dengan sangat tepat. Umumnya, metode ini dapat dilakukan dengan sangat efisien. Obyek kalibrasi biasanya terdiri dari dua atau tiga bidang yang terletak secara orthogonal satu dengan yang lainnya.

- Self Calibration. Metode-metode pada kategori ini tidak menggunakan obyek kalibrasi. Metode ini dilakukan dengan cara menggerakkan kamera pada pemandangan statis (static scene), yang dibatasi oleh parameter internal kamera dari perubahan letak kamera dengan menggunakan informasi yang terdapat pada gambar saja. Oleh karena itu, jika beberapa gambar diambil oleh kamera yang sama dengan parameter internal yang sama, hubungan antara gambar-gambar yang ada cukup untuk mendapatkan parameter internal dan eksternal yang ada.
Metode yang digunakan untuk melakukan proses rekonstruksi gambar 3D ini dikembangkan oleh Zhang [5]. Metode ini merupakan kombinasi dari Photogrammetric Calibration dan Self Calibration, karena menggunakan informasi metrik 2D dan menghasilkan informasi yang meliputi parameter intrinsik dan ekstrinsik yang akan digunakan dalam proses penghitungan letak benda dalam ruang 3D.

Parameter intrinsik ini terdiri dari empat unsur, yaitu nilai fokus kamera, yang merupakan jarak antara lensa kamera dengan bidang gambar, titik pusat proyeksi, yang merupakan lokasi titik tengah gambar dalam koordinat pixel, ukuran pixel efektif dan koefisien distorsi yang merupakan koefisien tingkat kelengkungan lensa yang meliputi radial dan tangensial distorsi.

Sedangkan parameter ekstrinsik ini terdiri dari dua buah matriks, yaitu matriks translasi dan matriks rotasi. Parameter ekstrinsik ini menggambarkan orientasi posisi dari kamera terhadap sistem koordinat sebenarnya dalam ruang 3D (world coordinate). Perhitungan untuk melakukan proyeksi dari 3D menuju 2D terdapat pada rumus (1) [5].

$$
\left[\begin{array}{l}
u \\
v \\
1
\end{array}\right]=\left[\begin{array}{ccc}
f x & 0 & C x \\
0 & f y & C y \\
0 & 0 & 1
\end{array}\right] \times\left[\begin{array}{llll}
r_{11} & r_{12} & r_{13} & t_{1} \\
r_{21} & r_{22} & r_{23} & t_{2} \\
r_{31} & r_{32} & r_{33} & t_{3}
\end{array}\right] \times\left[\begin{array}{l}
X \\
Y \\
Z \\
1
\end{array}\right]
$$

dimana (u,v) adalah koordinat 2D (camera coordinate), (X, Y, Z) adalah koordinat 3D (world coordinate). (fx, fy) adalah focus kamera, $(\mathrm{Cx}, \mathrm{Cy})$ adalah koordinat pusat gambar. Sedangakan $r_{11}$ hingga $r_{33}$ adalah matriks rotasi kamera serta $t_{1}$ hingga $t_{3}$ adalah matriks translasi kamera. Matriks-matriks tersebut didapat dari proses kalibrasi kamera.

\section{GENERALIZED VOXEL COLORING}

Generalized Voxel Coloring (GVC) adalah sebuah metode rekonstruksi gambar 3D dari beberapa gambar 2D. GVC menghasilkan rekonstruksi gambar 3D dengan menggunakan teori tentang visibility yang tepat dan penempatan kamera yang berubah-ubah.

Pada GVC terdapat dua varian, yaitu GVC-IB (Image Buffer) dan GVC-LDI (Layered Depth Image). GVC-LDI adalah perbaikan dari metode GVC-IB yang merupakan algoritma dasar dari GVC. Perbedaan dari kedua metode ini terletak pada penggunaan memori dan waktu yang diperlukan untuk melakukan proses rekonstruksi. Pada penelitian ini digunakan metode GVC-LDI dimana nanti pada saat pengujian dibandingkan juga dengan GVC-IB yang telah diimplementasikan sebelumnya [4]. 


\section{Generalized Voxel Coloring-Layered Depth Image}

Metode GVC bekerja dengan cara mengasumsikan awal sebuah ruang padat tiga dimensi yang tersusun atas voxel-voxel, dimana masing-masing voxel akan dievaluasi apakah dia merupakan bagian dari obyek atau bukan, dimana jika bukan merupakan bagian dari obyek akan dilakukan pemahatan terhadap voxel tersebut [2].

Pengevaluasian voxel dilakukan dengan memperhatikan photo-consistency dari pixel yang bersesuaian dengan voxel tersebut. Photo-consistency ini dihitung dengan menggunakan standar deviasi warna. Jadi untuk masing-masing pixel dari gambar-gambar 2D yang terproyeksi ke voxel yang sama dihitung apakah mempunyai standar deviasi lebih kecil daripada nilai threshold. Jika demikian, maka voxel tersebut merupakan bagian dari obyek, tetapi jika tidak, maka voxel tersebut akan dipahat. Proses evaluasi dilakukan mulai dari bagian permukaan ruang 3D menuju ke dalam sehingga pada akhirnya setelah tidak ada lagi voxel yang dapat dipahat, maka terbentuklah obyek 3 D yang dimaksud [3].

Pada saat terjadi pemahatan, maka terjadi pula perubahan visibility dari voxel tersebut. Dimana visibility ini adalah informasi yang menyatakan apakah voxel terlihat dari sudut pandang mata orang yang melihat. Untuk memperlihatkan perubahan masalah visibility, dapat dilihat pada Gambar 1 [2].

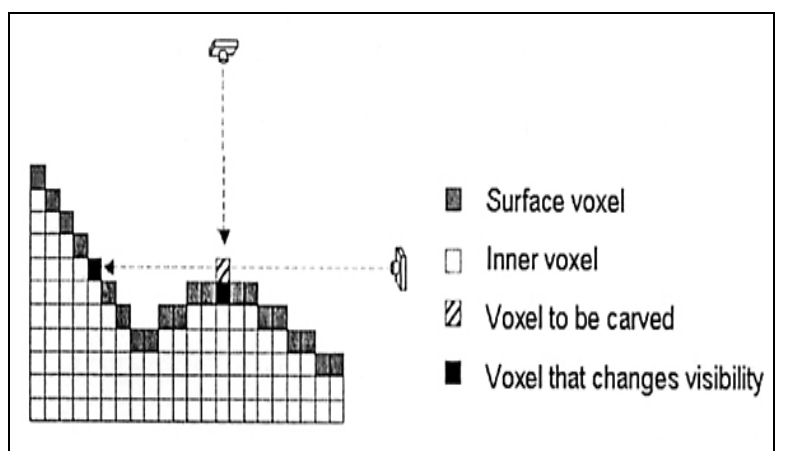

\section{Gambar 1. Voxel Visibility}

Jika terjadi perubahan visibility pada sebuah voxel, maka harus dihitung kembali photo consistency voxel tersebut.

Algoritma GVC-LDI menggunakan struktur data berupa link list untuk mencatat semua semua surface voxel yang terproyeksi pada pixel $P$. Hal ini ditunjukkan pada Gambar 3 [2].

Secara lengkap, algoritma GVC-LDI terdapat pada pseudocode Gambar 3 [2].

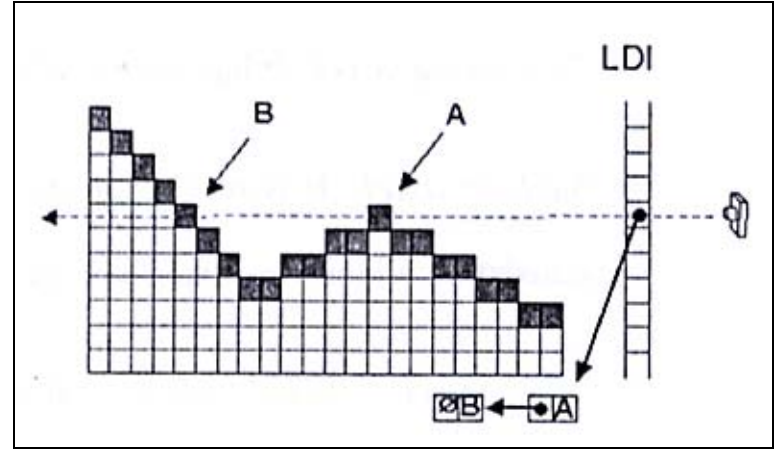

Gambar 2. Struktur Layered Depth Image

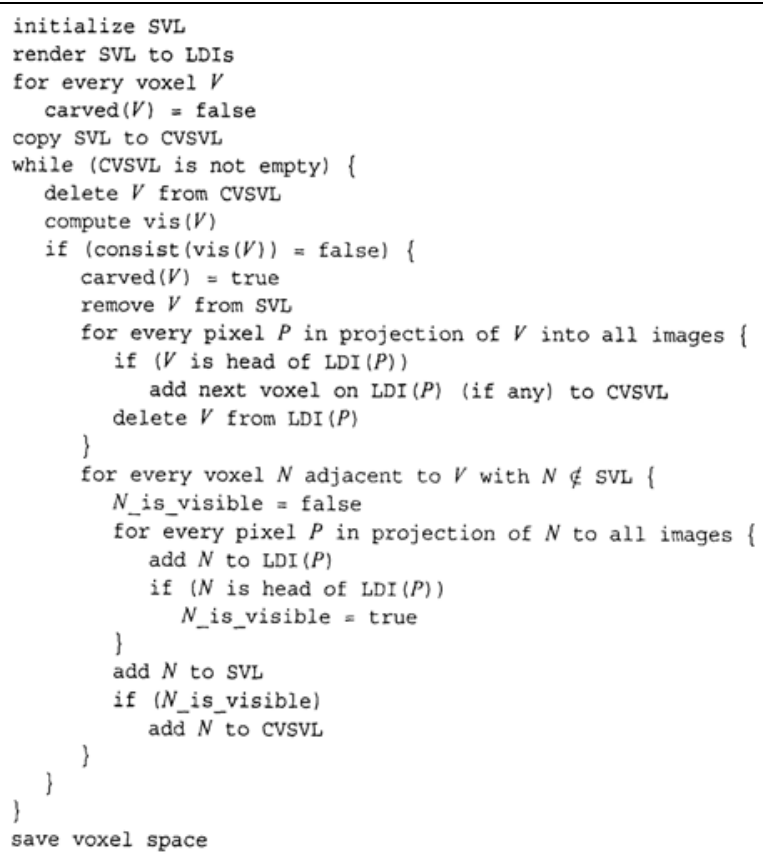

\section{Gambar 3. Pseudocode GVC-LDI}

\section{PERANCANGAN SISTEM}

Secara garis besar, sistem perangkat lunak rekonstruksi gambar 2D menjadi gambar 3D ini terdiri dari empat bagian, yaitu:

- Input

Proses input terdiri dari proses pengambilan gambar chessboard pattern guna kalibrasi kamera dan gambar obyek dengan menggunakan kamera digital. Gambar yang didapatkan akan digunakan sebagai input pada proses selanjutnya.

- Segmentation

Proses segmentation adalah proses untuk memisahkan obyek dengan lingkungan (latar belakang) sehingga memungkinkan sistem untuk hanya memproses obyek yang terdapat pada gambar. 


\section{- Camera Calibration}

Proses camera calibration berfungsi untuk mencari parameter intrinsik kamera dan mencari matrik ekstrinsik tiap gambar yang nantinya digunakan untuk melakukan transformasi dari 3D (world coordinate) ke 2D (camera coordinate).

- 3D Reconstruction

$3 D$ Reconstruction adalah proses utama dari perangkat lunak, yaitu proses rekonstruksi obyek 3D dengan metode generalized voxel coloringlayered depth image.

Input yang dibutuhkan oleh sistem terdiri dari dua yaitu input gambar 2D yang akan direkonstruksi serta input gambar chessboard pattern. Gambar chessboard pattern ini digunakan untuk proses kalibrasi kamera dimana titik-titik sudut pada chessboard pattern digunakan untuk inisialisasi pemetaan antara koordinat $3 \mathrm{D}$ dan $2 \mathrm{D}$ yang telah diketahui.
Sebelum dilakukan proses rekonstruksi, input gambar 2D terlebih dahulu harus dilakukan segmentasi untuk memisahkan antara gambar obyek dengan latar belakang. Proses segmentasi ini dilakukan dengan menggunakan metode iterative threshold. Pada proses ini, tiap pixel akan dipetakan ke dalam sebuah histogram menurut nilai grayscalenya. Kemudian, dicari nilai threshold sementara dan dilakukan proses segmentasi awal. Proses ini akan berulang selama nilai threshold yang baru masih berbeda jauh dari nilai threshold sebelumnya. Diagram alir proses segmentasi dapat dilihat pada Gambar 4.

Setelah selesai proses segmentasi, dapat dilakukan proses kalibrasi kamera dimana diagram alir untuk proses kalibrasi kamera ini terdapat pada Gambar 5. Proses utama dari sistem adalah proses GVC-LDI itu sendiri dimana diagram alir untuk proses ini dapat dilihat pada Gambar 6 .

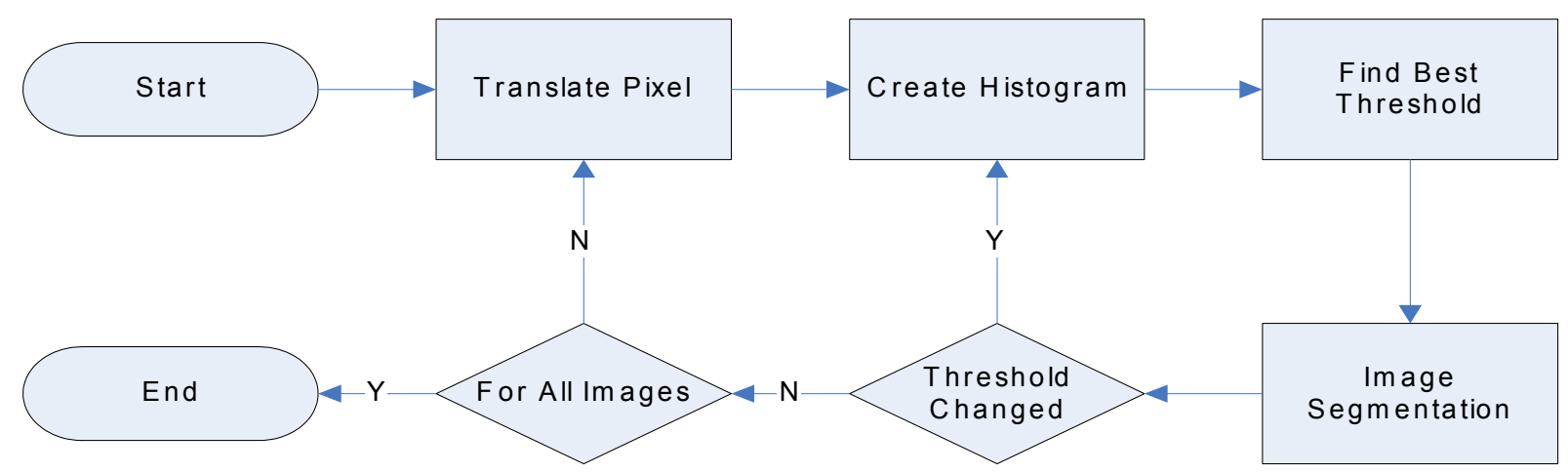

Gambar 4. Diagram Alir Proses Segmentasi

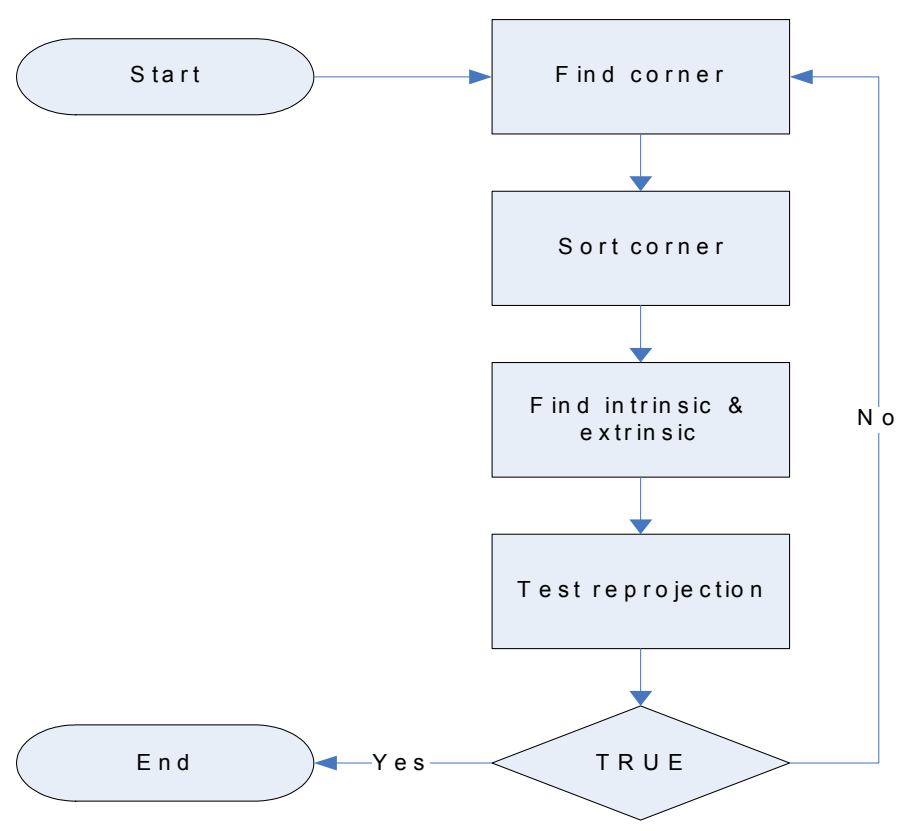

Gambar 5. Diagram Alir Proses Kalibrasi Kamera 


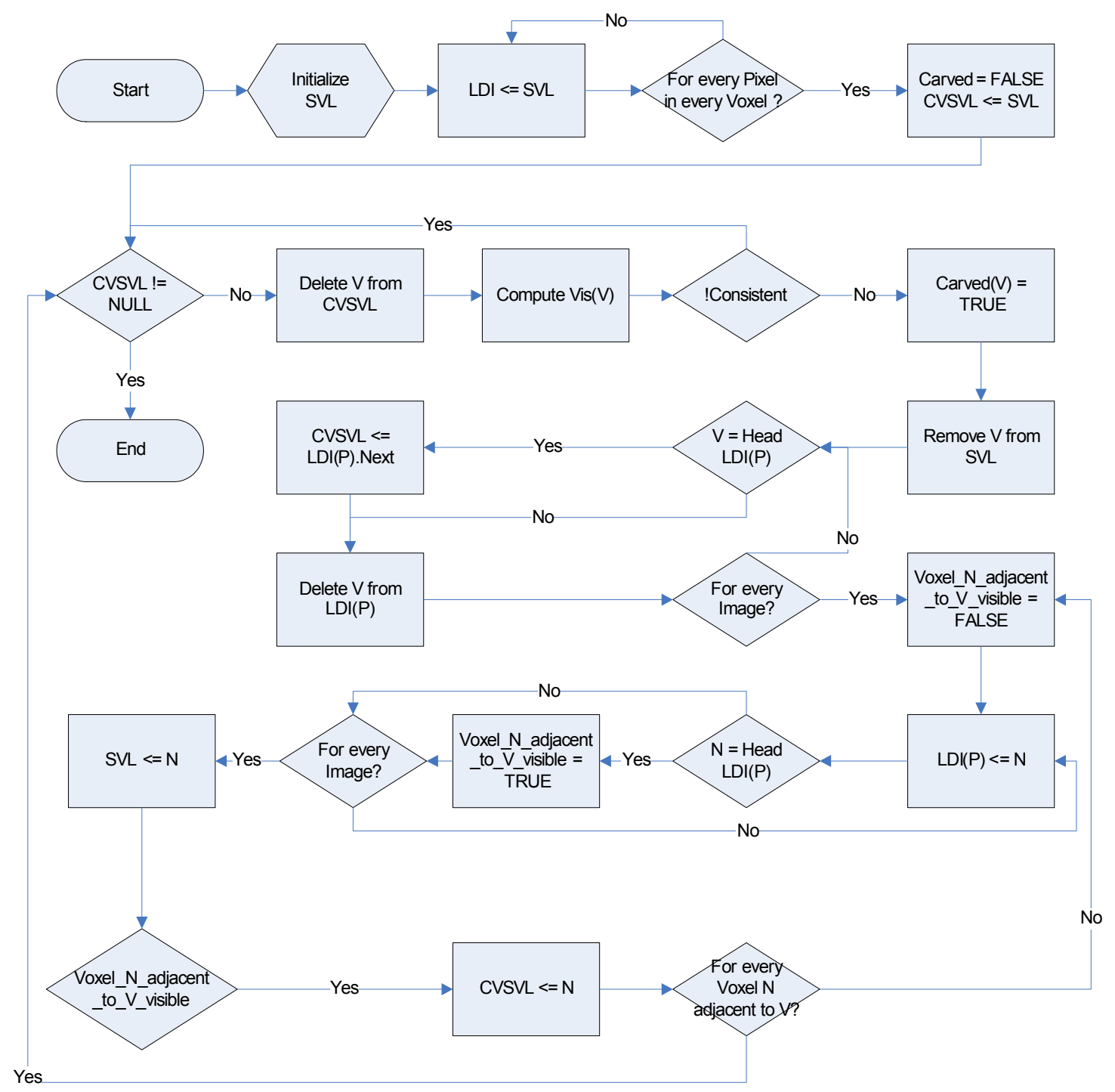

Gambar 6. Diagram Alir Generalized Voxel Coloring - Layered Depth Image

\section{IMPLEMENTASI DAN HASIL PENGUJIAN}

Aplikasi ini dikembangkan menggunakan bahasa pemrograman Microsoft Visual $\mathrm{C}++$ 6.0. Untuk proses kalibrasi kamera digunakan fungsi-fungsi yang terdapat pada library OpenCV [6], dan untuk menampilkan hasil rekonstruksi ke layar monitor digunakan fungsi-fungsi yang terdapat pada library OpenGL [7].

Pada saat pengujian digunakan parameterparameter seperti terdapat pada Tabel 1.
Tabel 1. Parameter Pengujian

\begin{tabular}{lc}
\hline $\begin{array}{l}\text { Ukuran chessboard pattern } \\
\text { dan ukuran setiap kotak }\end{array}$ & $5 \times 7$ kotak, $10 \mathrm{~mm}^{2}$ \\
\hline $\begin{array}{l}\text { Jumlah gambar input dan } \\
\text { perubahan sudut }\end{array}$ & 12 gambar, 30 \\
\hline Ukuran gambar input & $640 \times 480$ pixel \\
\hline Ukuran voxel & $1 \mathrm{~mm}^{3}$ \\
\hline Nilai threshold pembanding & $25,75,125,175$ \\
\hline
\end{tabular}

Pada pengujian ini digunakan 12 gambar dimana 3 gambar terlihat pada Gambar 7. 

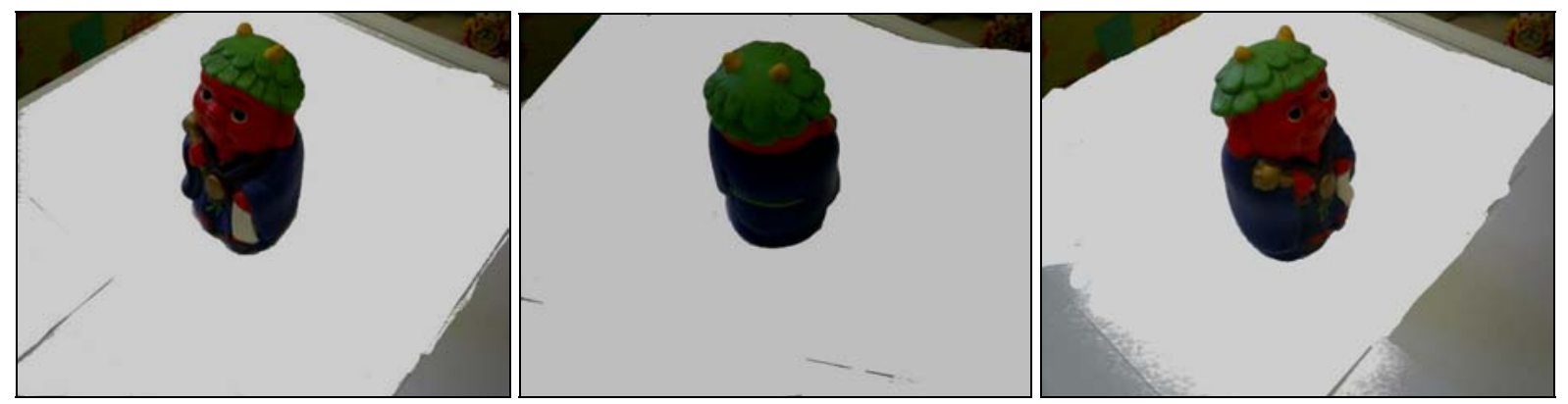

\section{Gambar 7. Tiga Gambar dari 12 Gambar Input}

Proses rekonstruksi dilakukan pada volume 40 $\mathrm{mm} \times 60 \mathrm{~mm} \times 80 \mathrm{~mm}$. Hasil proses rekonstruksi dengan gambar input serta parameter yang ditunjukkan pada Tabel 1 dapat dilihat pada Gambar 8.

Guna mendapatkan hasil yang baik perlu dilakukan percobaan rekonstruksi dengan nilai threshold yang berbeda-beda. Gambar 9 adalah gambar hasil pengaruh variasi nilai threshold pada rekonstruksi 3D.

Hasil rekonstruksi yang didapat dengan menggunakan GVC-LDI dibandingkan pula dengan hasil rekonstruksi dengan menggunakan metode GVC-IB yang telah dilakukan pada penelitian sebelumnya [4]. Hasil perbandingan dapat dilihat pada Tabel 2.
Tabel 2. Perbandingan Metode GVC-IB dan GVC-LDI

\begin{tabular}{|c|c|c|c|c|c|c|c|c|}
\hline Metode & & GVC & C-IB & & & GV & -LDI & \\
\hline Threshold & 10 & 30 & 75 & 100 & 10 & 30 & 75 & 100 \\
\hline $\begin{array}{l}\text { Jumlah proses } \\
\text { evaluasi (ribuan) }\end{array}$ & 26,02 & 47,3 & 75,4 & 92,9 & 3,96 & 3,87 & 3,81 & 3,80 \\
\hline Jumlah voxel hasil & 1687 & 3539 & 5509 & 7497 & 1687 & 1851 & 1969 & 1987 \\
\hline $\begin{array}{l}\text { Waktu Proses (dalam } \\
\text { detik) }\end{array}$ & 0,3 & 1,1 & 1,4 & 1,6 & 158 & 171 & 173 & 178 \\
\hline $\begin{array}{l}\text { Jumlah Memory } \\
\text { (dalam Mb) }\end{array}$ & 54,7 & 56,5 & 54,5 & 54,3 & 73,1 & 72,8 & 72,8 & 71,7 \\
\hline
\end{tabular}

Dari hasil pengujian pada Tabel 2, terlihat bahwa GVC-LDI unggul dalam hal jumlah proses evaluasi

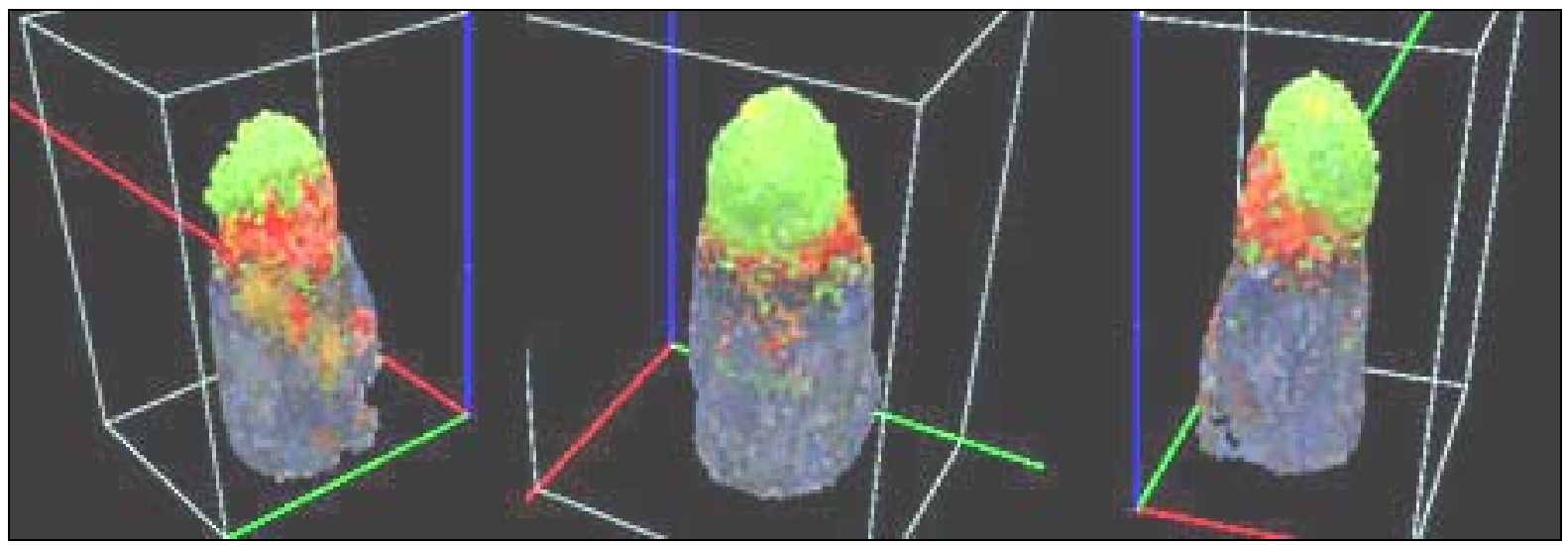

Gambar 8. Hasil Rekonstruksi

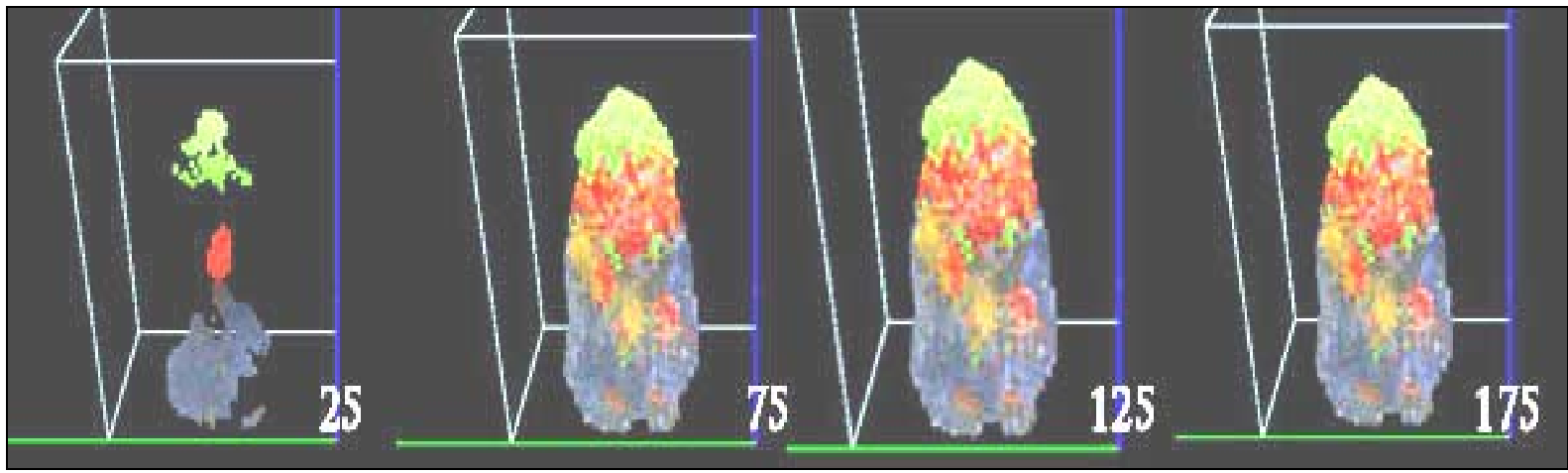

Gambar 9. Pengujian Terhadap Nilai Threshold 
(semakin sedikit jumlah proses evaluasi, semakin baik metode tersebut). Voxel yang dihasilkan oleh GVCLDI mempunyai jumlah yang lebih sedikit dibanding GVC-IB terutama untuk threshold yang besar, hal ini menunjukkan banyak voxel yang tidak diperlukan dapat tereliminasi walaupun threshold yang digunakan besar. Tetapi kelemahan GVC-LDI adalah pada waktu proses yang sangat lama serta jumlah memori yang dibutuhkan juga lebih besar dari memori yang dibutuhkan oleh GVC-IB.

Selain melakukan pengujian terhadap hasil rekonstruksi secara visual, dilakukan pula pengujian terhadap ketepatan posisi yang dihasilkan. Pada pengujian ini digunakan pattern sederhana untuk mengetahui sejauh mana selisih posisi antara obyek asli dengan obyek hasil rekonstruksi. Untuk itu dilakukan pengukuran pada beberapa titik, yang diambil pada titik-titik yang mudah dicari posisinya (dalam koordinat) dan dibandingkan antara benda asli terhadap hasil rekonstruksi. Gambar pattern yang digunakan untuk pengujian ini dapat dilihat pada Gambar 10. berikut.

Hasil perbandingan dapat dilihat pada Tabel 3

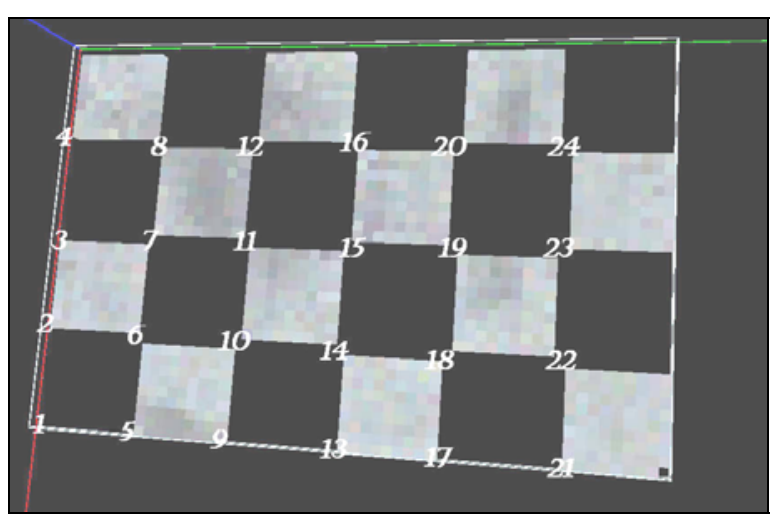

Gambar 10. Obyek Chessboard Pattern Guna Pengujian Ketepatan

Tabel 3. Perbandingan Ketepatan Posisi

\begin{tabular}{cccccccccc}
\hline \multirow{2}{*}{ Titik } & $\begin{array}{c}\text { PosX PosY PosX PosY } \\
\text { Asli }\end{array}$ & \multicolumn{2}{c}{ Asli } & Hasil Hasil & PosX & PosY & Pos X & PosY \\
Asli & Asli & Hasil & Hasil \\
\hline $\mathbf{1}$ & 0 & 0 & 0 & 0 & $\mathbf{1 3}$ & 0 & 30 & 0 & 30 \\
$\mathbf{2}$ & 10 & 0 & 10 & 0 & $\mathbf{1 4}$ & 10 & 30 & 10 & 30 \\
$\mathbf{3}$ & 20 & 0 & 20 & 0 & $\mathbf{1 5}$ & 20 & 30 & 20 & 30 \\
$\mathbf{4}$ & 30 & 0 & 30 & 0 & $\mathbf{1 6}$ & 30 & 30 & 30 & 30 \\
$\mathbf{5}$ & 0 & 10 & 0 & 10 & $\mathbf{1 7}$ & 0 & 40 & 0 & 40 \\
$\mathbf{6}$ & 10 & 10 & 10 & 10 & $\mathbf{1 8}$ & 10 & 40 & 10 & 40 \\
$\mathbf{7}$ & 20 & 10 & 20 & 10 & $\mathbf{1 9}$ & 20 & 40 & 20 & 40 \\
$\mathbf{8}$ & 30 & 10 & 30 & 10 & $\mathbf{2 0}$ & 30 & 40 & 30 & 40 \\
$\mathbf{9}$ & 0 & 20 & 0 & 20 & $\mathbf{2 1}$ & 0 & 50 & 0 & 50 \\
$\mathbf{1 0}$ & 10 & 20 & 10 & 20 & $\mathbf{2 2}$ & 10 & 50 & 10 & 50 \\
$\mathbf{1 1}$ & 20 & 20 & 20 & 20 & $\mathbf{2 3}$ & 20 & 50 & 20 & 50 \\
$\mathbf{1 2}$ & 30 & 20 & 30 & 20 & $\mathbf{2 4}$ & 30 & 50 & 30 & 50 \\
\hline
\end{tabular}

Dari hasil pengujian pada Tabel 3 terlihat bahwa posisi yang dihasilkan pada proses rekonstruksi sama dengan posisi pada gambar asli.

\section{KESIMPULAN}

Berdasarkan percobaan yang telah dilakukan maka dapat disimpulkan beberapa hal, antara lain:

- Nilai threshold pada proses rekonstruksi sangat mempengaruhi obyek 3D hasil rekonstruksi. Nilai threshold yang terlalu kecil akan membuat adanya voxel dari obyek yang seharusnya valid namun ikut terpahat, sedangkan nilai threshold yang terlalu besar akan menyebabkan adanya voxel dari lingkungan (background) yang dianggap valid sehingga ikut ditampilkan. Perlu dilakukan proses rekonstruksi secara berulang-ulang untuk menentukan nilai threshold yang cocok (tepat) sehingga menghasilkan obyek rekonstruksi 3D yang paling baik. Nilai threshold yang baik berada antara 50 sampai 100.

- Dari pengujian perbandingan antara metode GVCLDI dengan GVC-IB, didapat bahwa proses rekonstruksi dengan menggunakan metode GVCLDI mempunyai algoritma iterasi yang lebih efisien dibanding GVC-IB sehingga proses evaluasi yang dilakukan lebih sedikit dan menghasilkan voxel yang lebih sedikit pula walaupun dengan menggunakan threshold besar.

Metode GVC-LDI mempunyai kekurangan dibanding metode GVC-IB yaitu membutuhkan memori yang sangat besar saat menjalankan proses serta membutuhkan waktu proses yang lebih lama.

\section{DAFTAR PUSTAKA}

1. Izquierdo, E., and J. R. Ohm. Image-based rendering and $3 D$ modeling:A Complete Framewor, . Signal Processing: Image Communication 15, 2000, pp. 817-858.

2. Slabaugh, Gregory G., Novel Volumetric Scene Reconstruction Methods for New View Synthesis. USA: Georgia Institute of Technology, 2002.

3. Seitz, Steven M., and Charles R. Dyer, Photorealistic Scene Reconstruction by Voxel Coloring. Proc. Computer Vision and Pattern Recognition Conf, 1997, pp.1067-1073.

4. Adipranata, Rudy, Resmana Lim, dan Anton Setiawan, Rekonstruksi Obyek 3D dari Gambar 2D Dengan Metode Generalized Voxel Coloring. Prosiding Seminar Nasional KOMMIT, Jakarta. 2006.

5. Zhang, Zhengyou, A Flexible New Technique for Camera Calibration. PDF, 2002. 
6. Open CV Documentation by Intel Research. $<$ http://sourceforge.net/projects/opencv/>, akses: 3 Maret 2005.
7. Wright, Richard S., and Benjamin Lipchak, OpenGL Superbible (3rd ed). Indianapolis: Sams Publishing, 2005. 